\title{
Quantification of environmentally persistent free radicals and reactive oxygen species in atmospheric aerosol particles
}

\author{
Andrea M. Arangio ${ }^{1}$, Haijie Tong ${ }^{1}$, Joanna Socorro ${ }^{1}$, Ulrich Pöschl ${ }^{1}$, and Manabu Shiraiwa ${ }^{1,2}$ \\ ${ }^{1}$ Multiphase Chemistry Department, Max Planck Institute for Chemistry, Mainz, Germany \\ ${ }^{2}$ Department of Chemistry, University of California, Irvine, CA, USA \\ Correspondence to: Manabu Shiraiwa (m.shiraiwa@uci.edu)
}

Received: 13 June 2016 - Published in Atmos. Chem. Phys. Discuss.: 20 June 2016

Revised: 4 October 2016 - Accepted: 12 October 2016 - Published: 26 October 2016

\begin{abstract}
Fine particulate matter plays a central role in the adverse health effects of air pollution. Inhalation and deposition of aerosol particles in the respiratory tract can lead to the release of reactive oxygen species (ROS), which may cause oxidative stress. In this study, we have detected and quantified a wide range of particle-associated radicals using electron paramagnetic resonance (EPR) spectroscopy. Ambient particle samples were collected using a cascade impactor at a semi-urban site in central Europe, Mainz, Germany, in May-June 2015. Concentrations of environmentally persistent free radicals (EPFR), most likely semiquinone radicals,

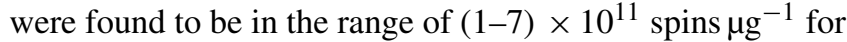
particles in the accumulation mode, whereas coarse particles with a diameter larger than $1 \mu \mathrm{m}$ did not contain substantial amounts of EPFR. Using a spin trapping technique followed by deconvolution of EPR spectra, we have also characterized and quantified ROS, including $\mathrm{OH}$, superoxide $\left(\mathrm{O}_{2}^{-}\right)$and carbon- and oxygen-centered organic radicals, which were formed upon extraction of the particle samples in water. Total ROS amounts of $(0.1-3) \times 10^{11}$ spins $\mu g^{-1}$ were released by submicron particle samples and the relative contributions of $\mathrm{OH}, \mathrm{O}_{2}^{-}, \mathrm{C}$-centered and $\mathrm{O}$-centered organic radicals were $\sim 11-31, \sim 2-8, \sim 41-72$ and $\sim 0-25 \%$, respectively, depending on particle sizes. $\mathrm{OH}$ was the dominant species for coarse particles. Based on comparisons of the EPR spectra of ambient particulate matter with those of mixtures of organic hydroperoxides, quinones and iron ions followed by chemical analysis using liquid chromatography mass spectrometry (LC-MS), we suggest that the particle-associated ROS were formed by decomposition of organic hydroperoxides interacting with transition metal ions and quinones contained in atmospheric humic-like substances (HULIS).
\end{abstract}

\section{Introduction}

Epidemiological studies have clearly shown positive correlations between respiratory diseases and ambient fine particulate matter (Pope and Dockery, 2006; Strak et al., 2012; West et al., 2016). A recent study has estimated that outdoor air pollution leads to 3.3 million premature deaths per year worldwide, which is mostly due to particular matter with a particle diameter less than $2.5 \mu \mathrm{m}\left(\mathrm{PM}_{2.5}\right)$ (Lelieveld et al., 2015). Plausible reasons include the cytotoxicity of ambient $\mathrm{PM}_{2.5}$ and its ability to induce inflammatory responses by oxidative stress causing functional alterations of pulmonary epithelial cells (Nel, 2005; Gualtieri et al., 2009). Oxidative stress is mediated by reactive oxygen species (ROS), including $\mathrm{OH}, \mathrm{H}_{2} \mathrm{O}_{2}$ and superoxide $\left(\mathrm{O}_{2}^{-}\right)$, as well as organic radicals (Pryor et al., 1995; Winterbourn, 2008; Birben et al., 2012; Pöschl and Shiraiwa, 2015). Upon PM deposition into the respiratory tract and interactions with lung antioxidants, $\mathrm{H}_{2} \mathrm{O}_{2}$ can be generated by redox-active components contained in $\mathrm{PM}_{2.5}$ such as transition metals (Charrier et al., 2014; Fang et al., 2016), semiquinones (Kumagai et al., 1997; Cho et al., 2005; Khachatryan et al., 2011; McWhinney et al., 2013) and humic-like substances (Kumagai et al., 1997; Cho et al., 2005; Lin and Yu, 2011; Charrier et al., 2014; Dou et al., 2015; Fang et al., 2016; Verma et al., 2015a). $\mathrm{H}_{2} \mathrm{O}_{2}$ can be converted into highly reactive $\mathrm{OH}$ radicals via Fenton-like reactions with iron and copper ions (Charrier et al., 2014; Enami et al., 2014).

Ambient particles have been found to contain large amounts of ROS (mostly $\mathrm{H}_{2} \mathrm{O}_{2}$ ) in the particle phase (Hung and Wang, 2001; Venkatachari et al., 2005, 2007; Fuller et al., 2014). Substantial amounts of particle-bound ROS are 
found on biogenic secondary organic aerosols (SOA) produced from the oxidation of $\alpha$-pinene, linalool, and limonene (Chen and Hopke, 2010; Chen et al., 2011; Pavlovic and Hopke, 2011; Wang et al., 2011, 2012). Recently, Tong et al. (2016) have shown that terpene and isoprene SOA can form $\mathrm{OH}$ radicals upon interactions with liquid water and iron ions under dark conditions. This can be explained by the decomposition of organic hydroperoxides, which account for the predominant fraction of SOA mass and are generated via multigenerational oxidation and autoxidation (Docherty et al., 2005; Ziemann and Atkinson, 2012; Crounse et al., 2013; Ehn et al., 2014; Epstein et al., 2014; Badali et al., 2015).

In addition, $\mathrm{PM}_{2.5}$ contains environmentally persistent free radicals (EPFR) that can be detected directly by electron paramagnetic resonance (EPR) spectroscopy (Dellinger et al., 2001; Khachatryan et al., 2011; Gehling and Dellinger, 2013). EPFR are stable radicals with an $e$ folding lifetime exceeding one day (Gehling and Dellinger, 2013; Jia et al., 2016). The chemical nature of EPFR is remarkably similar to semiquinone radicals, which can be stabilized via electron transfer with transition metals in the particle phase (Truong et al., 2010; Vejerano et al., 2011; Gehling and Dellinger, 2013). EPFR are formed upon combustion and pyrolysis of organic matter (Dellinger et al., 2001, 2007). The formation of stable radicals can also be induced by heterogeneous and multiphase chemistry of organic aerosols. Heterogeneous ozonolysis of aerosol particles such as polycyclic aromatic hydrocarbons (PAH) and pollen proteins can lead to the formation of long-lived reactive oxygen intermediates (ROI) (Shiraiwa et al., 2011, 2012; Reinmuth-Selzle et al., 2014; Borrowman et al., 2015; Kampf et al., 2015; Berkemeier et al., 2016).

In this work, ambient particles with a diameter in the range of $56 \mathrm{~nm}$ to $3.2 \mu \mathrm{m}$ were collected using a cascade impactor during May-July 2015 in Mainz, Germany. Size dependences of EPFR concentrations contained in ambient particles have been measured using an EPR spectrometer. Particles were also extracted in water containing a spin-trapping agent followed by EPR analysis to quantify the formation of various radical forms of ROS, including $\mathrm{OH}$, superoxide $\left(\mathrm{O}_{2}^{-}\right)$and carbon- and oxygen-centered organic radicals.

\section{Methods}

Ambient particles were collected using a micro-orifice uniform deposition impactor (MOUDI, 110-R, MSP Corporation) on the roof of the Max Planck Institute for Chemistry, Mainz, Germany $\left(49.99^{\circ} \mathrm{N}, 8.23^{\circ} \mathrm{E}\right)$. The sampling was conducted every $24 \mathrm{~h}$ starting at 17:00 during 28 May9 June 2015. Particles were collected with a sampling time of $48 \mathrm{~h}$ during 26-27 June and 18-19 July 2015 in order to collect sufficiently high mass loadings for all stages of different particle size ranges. The sampling was conducted with a flow rate of $30 \mathrm{~L} \mathrm{~min}^{-1}$ with the following nominal lower cut-off particle diameters: $56,100,180,320,560 \mathrm{~nm}$, 1 , and $1.8 \mu \mathrm{m}$. Note that transmission and bouncing effects might have caused mixing of particles exhibiting relatively different sizes on one stage, particularly for coarse particles (Gomes et al., 1990; Bateman et al., 2014). Particles were collected on $47 \mathrm{~mm}$ diameter Teflon filters $(100 \mathrm{~nm}$ pore size, Merck Chemicals $\mathrm{GmbH}$ ). Before sampling, each filter was cleaned and sonicated for $10 \mathrm{~min}$ with pure ethanol and ultra-pure water and dried with nitrogen gas before weighing. Teflon filters were weighed four times using a balance (Mettler Toledo XSE105DU) and mounted in the MOUDI. After sampling, each filter was conditioned for at least $1 \mathrm{~h}$ $\left(22-23^{\circ} \mathrm{C}\right.$ and $\left.40-50 \% \mathrm{RH}\right)$ and weighted four times before being folded and inserted in a $4 \mathrm{~mm}$ EPR tube. Particles were extracted by immersing the filter into a solution containing $350 \mu \mathrm{L}$ of $20 \mathrm{mM}$ 5-tert-Butoxycarbonyl-5-methyl-1pyrroline-N-oxide (BMPO, high purity; Enzo Life Sciences, Inc.) and stirred with a vortex shaker (Heidolph Reax 1) for 7-9 min. BMPO is an efficient spin-trapping agent for $\mathrm{OH}$, $\mathrm{O}_{2}^{-}$and organic radicals (Zhao et al., 2001; Tong et al., 2016). Note that the trapping efficiency of $\mathrm{O}_{2}^{-}$and organic radicals might be lower compared to $\mathrm{OH}$ radicals, as the recent study has reported that nitrone-based spin traps have the highest reactivity towards $\mathrm{OH}$ and somewhat lower reactivity towards organic radicals and superoxide (Sueishi et al., 2015). Extracts were dried for approximately $14-17$ min under $1-3$ bar flow to reduce the volume of the solution to $50 \mu \mathrm{L}$, and then $20 \mu \mathrm{L}$ were used for EPR measurements.

A continuous-wave electron paramagnetic resonance (CW-EPR) X-band spectrometer (EMXplus-10/12; Bruker Corporation) was used for detection and quantification of stable radicals and ROS. Filters containing particles were folded and introduced into a $4 \mathrm{~mm}$ I.D. quartz tube and inserted directly into a high sensitivity cavity. EPR spectra were recorded at a room temperature of $23^{\circ} \mathrm{C}$ by setting the following operating parameters: a modulation frequency of $100 \mathrm{kHz}$; a microwave frequency of $9.84 \mathrm{GHz}$, a microwave power of $2.149 \mathrm{~mW}(20 \mathrm{db})$, a modulation amplitude of $1.0 \mathrm{G}$, a sweep width of $110.0 \mathrm{G}$, a sweep time of $175 \mathrm{~s}$, a receiver gain of $40 \mathrm{db}$, a time constant of $40.96 \mathrm{~ms}$, a conversion time of $160 \mathrm{~ms}$ and a scan number of 6 . Paramagnetic species are characterized based on their $g$ factor values. Free electrons have a $g$ factor value of 2.0023 and organic radicals have higher $g$ factor values (2.0030-2.0060), depending on the number of oxygen atoms in the molecule (Dellinger et al., 2007).

The spin-counting method embedded in the Bruker software, Xenon, was used to quantify detected radicals. The spin-counting method was calibrated using a standard compound 4-hydroxy-2,2,6,6-tetramethylpiperidin-1oxyl (TEMPOL). The detection limit of EPR was $\sim 1 \times$ $10^{10}$ spins $\mu \mathrm{g}^{-1}$. Concentrations of EPFR and ROS are reported in the unit of spins $\mu \mathrm{g}^{-1}$, which indicates the number 


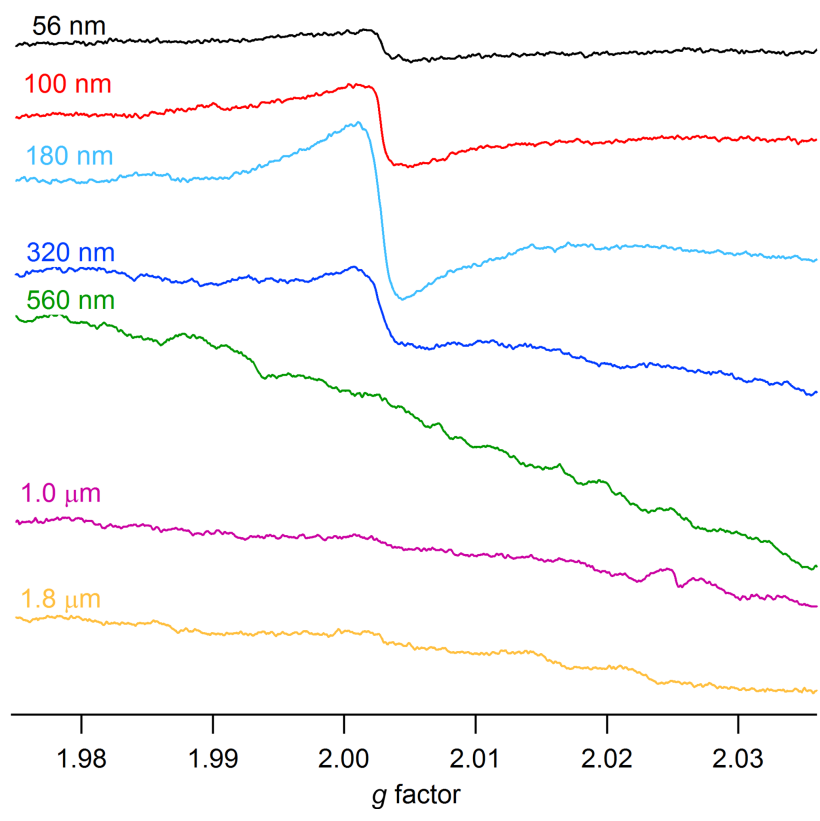

Figure 1. Electron paramagnetic resonance (EPR) spectra of atmospheric aerosol impactor samples with lower cut-off diameters in the range of $56 \mathrm{~nm}$ to $1.8 \mu \mathrm{m}$ collected in Mainz, Germany, during 26-27 June, 2015.

of spins (or radicals) per $\mu \mathrm{g}$ of particle mass. For better quantification and determination of the relative contributions of $\mathrm{OH}, \mathrm{O}_{2}^{-}$, carbon-centered and oxygen-centered organic radicals, EPR spectra were fitted and simulated using Xenon and the MATLAB-based computational package EasySpin (Stoll and Schweiger, 2006).

\section{Results and discussion}

\subsection{Environmentally persistent free radicals}

Figure 1 shows EPR spectra of ambient particles in the lower cut-off diameter range of $56 \mathrm{~nm}-1.8 \mu \mathrm{m}$. Fine particles, with lower cut-off diameters of $56-320 \mathrm{~nm}$, show a single and unstructured peak with a $g$ factor of $\sim 2.003$ and with a peak to peak distance $\left(\Delta H_{\mathrm{p}-\mathrm{p}}\right)$ ranging from 3 to $8 \mathrm{G}$. Such spectra are characteristic for EPFR, which have been attributed to semiquinone radicals (Dellinger et al., 2001, 2007; Vejerano et al., 2011; Bahrle et al., 2015). Particles with a diameter smaller than $56 \mathrm{~nm}$ and larger than $560 \mathrm{~nm}$ did not show significant signals, indicating the reduced amount of EPFR in these size ranges. EPR spectra for particles with the lower cut-off diameters of 56-320 nm for each sampling day are presented in Fig. A1 in the Appendix.

The black line in Fig. 2 shows the size distribution of EPFR concentrations. Particles with different sizes had different radical contents and particles with the lower cut-off diameter of $100 \mathrm{~nm}$ contained the highest EPFR concentrations of $7.0( \pm 0.7) \times 10^{11}$ spins $\mu g^{-1}$. High abundances of EPFR

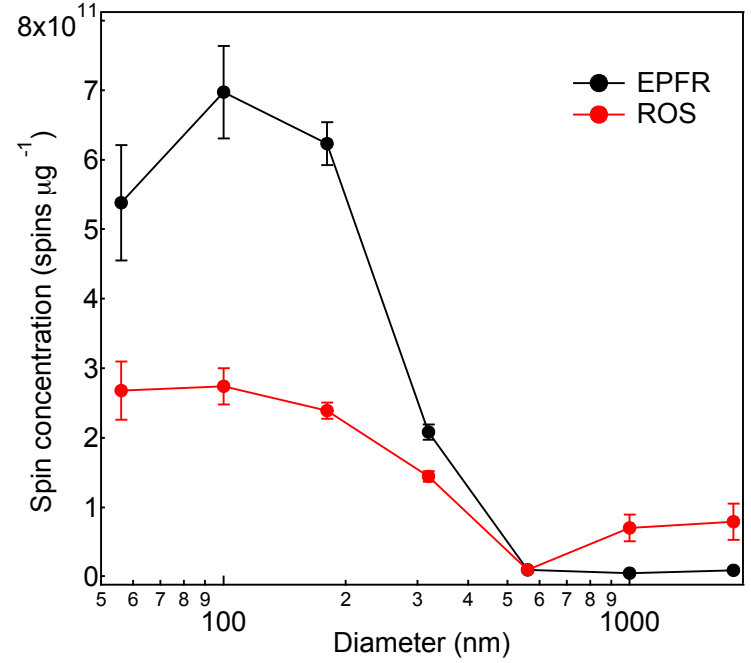

Figure 2. Concentrations (spins per microgram of particles) of environmentally persistent free radicals (EPFR) and radical forms of reactive oxygen species (ROS) in atmospheric aerosol samples plotted against particle diameter. The error bars represent standard errors based on uncertainties in the particle mass and signal integration of EPR spectra.

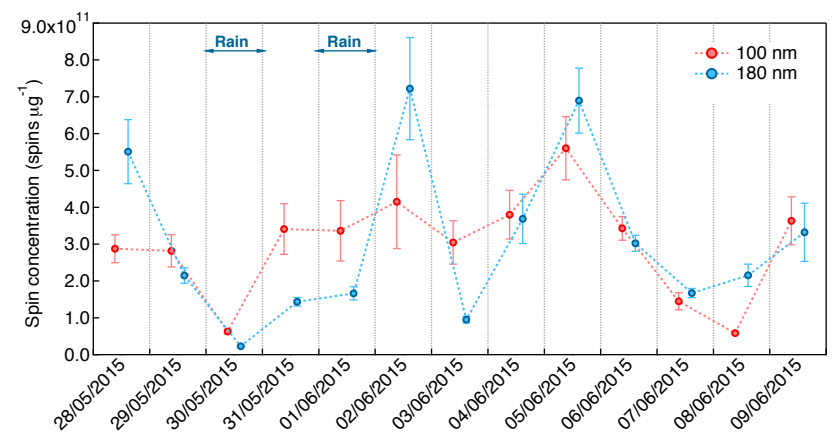

Figure 3. Temporal evolution of concentrations of environmentally persistent free radicals (EPFR) contained in atmospheric aerosol samples with lower cutoff diameters of $100 \mathrm{~nm}$ (red) and $180 \mathrm{~nm}$ (blue), measured in Mainz, Germany, during May-June 2015. The error bars represent standard errors based on uncertainties in the particle mass and signal integration of EPR spectra.

in particles in the accumulation mode is consistent with mass size distributions of combustion-generated particles, such as soot or black carbon, which typically have peak concentrations around 100-200 nm (Bond et al., 2013). This observation is in line with the fact that EPFR may often be associated with soot particles (Dellinger et al., 2007).

Figure 3 shows the temporal evolution of EPFR concentrations contained in particles with lower cut-off diameters of 100 and $180 \mathrm{~nm}$. During the sampling period of 2 weeks, there were two rain events (on 30 May and 1 June 2015) and three sunny days (4-6 June 2015), and the other days were cloudy. The mass concentrations of particles within the di- 
(a)

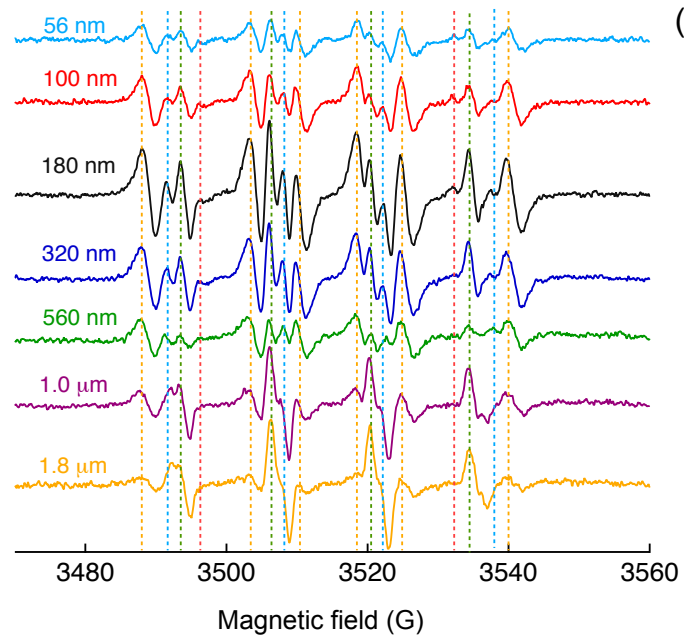

(b)

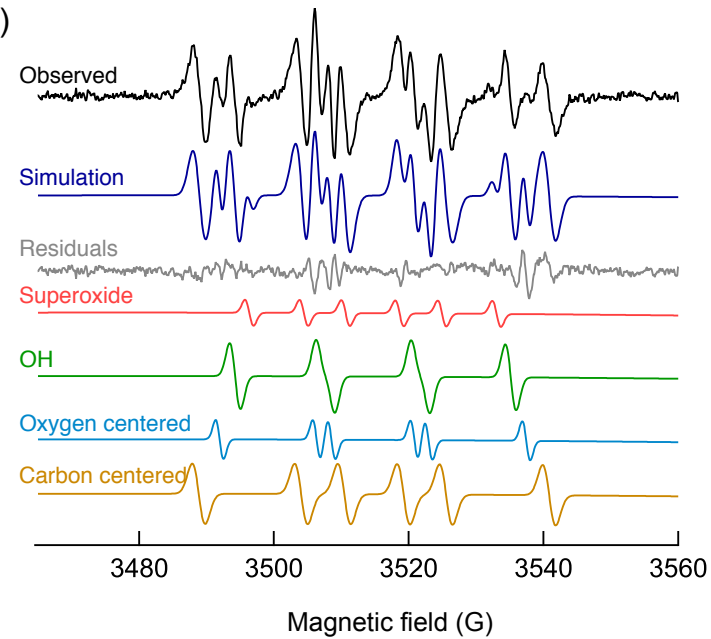

Figure 4. (a) Electron paramagnetic resonance (EPR) spectra of ambient aerosol impactor samples (Mainz, Germany; 26-27 June 2015) with lower cut-off diameters in the range of $56 \mathrm{~nm}$ to $1.8 \mu \mathrm{m}$ extracted in water mixed with the spin-trapping agent BMPO. Dashed lines indicate the position of each peak for different types of trapped radicals of $\mathrm{O}_{2}^{-}$(red), $\mathrm{OH}$ (green), carbon-centered (orange) and oxygen-centered organic radicals (light blue). (b) Simulation of the EPR spectrum of the atmospheric aerosol impactor sample with particle diameters in the range of 180-320 nm (lower to upper cut-off) by deconvolution into $\mathrm{O}_{2}^{-}, \mathrm{OH}$, O-centered and C-centered organic radicals (Blue is synthesis, grey is residual).

ameters of 56-560 $\mathrm{nm}$ were in the range of 3.9-12.8 $\mu \mathrm{g} \mathrm{m}^{-3}$. Maximum values of $\sim 7 \times 10^{11}$ spins $\mu \mathrm{g}^{-1}$ were reached during sunny days, indicating that photochemistry may be related to EPFR production. For example, heterogeneous reactions of photo-oxidants including $\mathrm{O}_{3}$ and $\mathrm{OH}$ with soot or PAH may contribute to the formation of long-lived radicals (Shiraiwa et al., 2011; Borrowman et al., 2015). Radical con-

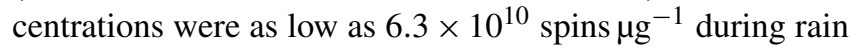
events, most likely due to low production of EPFR and scavenging by precipitation.

The EPFR concentration contained in particles within the diameter of $56 \mathrm{~nm}-3.2 \mu \mathrm{m}$ collected for $48 \mathrm{~h}$ during 26 27 June 2015 was $\sim 2.2 \times 10^{11}$ spins $\mu g^{-1}$. EPFR concentrations contained in particles within the diameter of 56$560 \mathrm{~nm}$ averaged over the entire measurement period was $2.0( \pm 1.3) \times 10^{11}$ spins $\mu g^{-1}$. Squadrito et al. (2001) determined the EPFR concentrations to be in the range of (110) $\times 10^{11}$ spins $\mu \mathrm{g}^{-1}$ in $\mathrm{PM}_{2.5}$ sampled for $24 \mathrm{~h}$ in five different urban sites in the United States. Gehling et al. (2014) reported that the EPFR concentration was in the range of (755) $\times 10^{10}$ spins $\mu g^{-1}$ at a site in Louisiana near heavy interstate traffic along a major industrial corridor of the Mississippi River. Shaltout et al. (2015) measured radical concentrations in the range of $(2-6) \times 10^{10}$ spins $\mu \mathrm{g}^{-1}$ in $\mathrm{PM}_{2.5}$ collected in industrial-, residential- and traffic-dominated sites in Taif, Saudi Arabia. The EPFR concentrations measured in this work are comparable with these previous measurements.

\subsection{Reactive oxygen species}

Figure 4a shows EPR spectra of ambient particles with lower cut-off diameters of $56 \mathrm{~nm}-1.8 \mu \mathrm{m}$ extracted in water with the spin-trapping agent BMPO. Each EPR spectrum is composed of several overlapped lines, originating from different radical forms of ROS. Dashed lines indicate the positions of each peak for each type of trapped ROS, including $\mathrm{OH}$ (green), superoxide (red), carbon-centered (orange) and oxygen-centered organic radicals (light blue). The relative abundance of these radicals was different for each size range, causing the EPR spectral features to be highly variable. For example, spectra from particles larger than $1.0 \mu \mathrm{m}$ consist mainly of four peaks that are typical for $\mathrm{OH}$ radicals, whereas those for smaller particles contain more peaks indicating the presence of multiple radicals.

To estimate the relative amount of each type of ROS, the observed EPR spectra were fitted and simulated using the softwares EasySpin 5.0 and Xenon. Four types of radicals have been used to fit the spectra: BMPO-OH (hyperfine coupling constants of $a^{\mathrm{N}}=14.3 \mathrm{G}, a_{\beta}^{\mathrm{H}}=12.7 \mathrm{G}, a_{\gamma}^{\mathrm{H}}=$ $0.61 \mathrm{G})$, BMPO-OOH $\left(a^{\mathrm{N}}=14.3 \mathrm{G}, a^{\mathrm{H}}=8.1 \mathrm{G}\right)$, BMPO-R $\left(a^{\mathrm{N}}=15.2 \mathrm{G}, a^{\mathrm{H}}=21.6 \mathrm{G}\right)$ and BMPO-OR $\left(a^{\mathrm{N}}=14.5 \mathrm{G}\right.$, $\left.a_{\beta}^{\mathrm{H}}=16.6 \mathrm{G}\right)$. As shown in Fig. $4 \mathrm{~b}$, the simulated EPR spectrum reproduced the observed spectrum very well with a small residual. The deconvolution of spectra allowed us to estimate the relative contribution of four types of ROS within each particle size range.

Figure 5 shows the relative contributions of $\mathrm{OH}$ (green), superoxide (red), carbon-centered (orange) and oxygencentered (blue) organic radicals to the total radicals trapped 


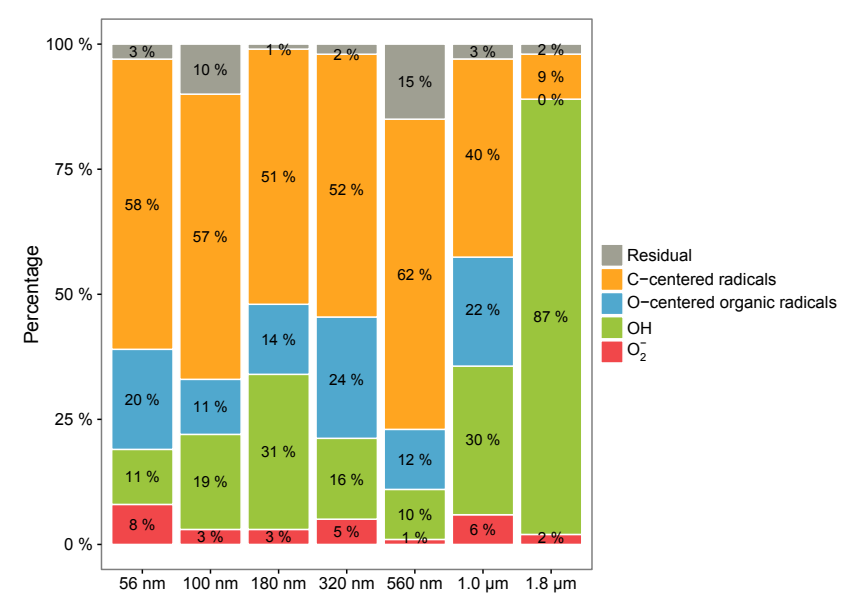

Figure 5. Relative amount of ROS in atmospheric aerosol impactor samples with lower cut-off diameters in the range of $50 \mathrm{~nm}-1.8 \mu \mathrm{m}$ (Mainz, Germany; 26-27 June 2015) are as follows: $\mathrm{O}_{2}^{-}$(red), $\mathrm{OH}$ (green), carbon-centered (orange), oxygen-centered organic radicals (blue) and residual (unidentified, grey).

by BMPO in water extracts of particles collected for $48 \mathrm{~h}$ during 26-27 June 2015. Carbon-centered radicals are the most abundant type of radicals, contributing $\sim 50-72 \%$ of total ROS for $\mathrm{PM}_{1}$. It decreases to 41 and $9 \%$ for particles with lower cut-off diameters of 1 and $1.8 \mu \mathrm{m}$, respectively. The $\mathrm{OH}$ radical accounts for $\sim 11-31 \%$ of total trapped radicals for $\mathrm{PM}_{1}$, whereas $\mathrm{OH}$ was the dominant species for coarse particles with diameters of 1.8-3.2 $\mu \mathrm{m}$. The least abundant radical for all size ranges was $\mathrm{O}_{2}^{-}$, with contributions of $\sim 2-8 \%$ and without any clear size dependence. The amount of oxygen-centered organic radicals ranges between 12 and $25 \%$ in particles with a diameter below $1 \mu \mathrm{m}$ and its contribution was negligible for coarse particles. Note that the contribution of oxygen-centered organic radicals for particles with a diameter of $1-1.8 \mu \mathrm{m}$ might be attributed to the $\mathrm{OH}$ radical, since the hyperfine coupling constants for BMPO-OR for better fitting the spectrum for this size range needed to be changed slightly $\left(a^{\mathrm{N}}=13.5 \mathrm{G}, a_{\beta}^{\mathrm{H}}=15.3 \mathrm{G}\right.$, $\left.a_{\gamma}^{\mathrm{H}}=0.6 \mathrm{G}\right)$. These values are similar to constants of a second conformer of BMPO-OH.

The red line in Fig. 2 shows the size-dependent concentrations of radical forms of ROS (e.g., sum of $\mathrm{OH}, \mathrm{O}_{2}^{-}, \mathrm{C}$ - and $\mathrm{O}$ - centered organic radicals). Particles with the lower cut-off diameter of $100 \mathrm{~nm}$ have the highest ROS concentrations of $2.7( \pm 0.2) \times 10^{11}$ spins $_{\mu g^{-1}}$. Concentrations are smaller for particles in the coarse mode with a diameter larger than $1 \mu \mathrm{m}$. This is consistent with previous studies, suggesting that particles in the accumulation mode are the most active in the ROS generation (Hung and Wang, 2001; Venkatachari et al., 2007; Saffari et al., 2013, 2014; Wang et al., 2013). The total concentration of radical forms of ROS was measured to be $1.2 \times 10^{11}$ spins $\mu \mathrm{g}^{-1}$. Note that $\mathrm{O}_{2}^{-}$concentrations might be underestimated as the lifetime of the BMPO-OOH adduct is relatively short ( $23 \mathrm{~min}$ ) (Ouari et al., 2011; Abbas et al., 2014).

Previous studies have measured redox activity and oxidative potential of PM by the dichlorofluorescein (DCFH) and dithiothreitol (DTT) assays. The DCFH assay is mostly sensitive to $\mathrm{H}_{2} \mathrm{O}_{2}$ and other peroxides. For example, Hung and Wang (2001) reported ROS concentrations as $1 \times 10^{13}{\mu \mathrm{g}^{-1}}^{-1}$ in Taipei, Taiwan. This value is very similar to $\mathrm{H}_{2} \mathrm{O}_{2}$ concentrations contained in ambient $\mathrm{PM}_{2.5}$, which has been quantified to be up to $1 \times 10^{13} \mu^{-1}$ in an urban environment in southern California using high-performance thinlayer chromatography (HPLC) fluorescence (Wang et al., 2012). The DTT assay is based on the decay of DTT due to redox reactions with PM components, reporting the oxidative potential of PM in moles of DTT consumed per unit of time and mass of PM. Verma et al. (2015a) and Fang et al. (2016) reported that $\mathrm{PM}_{2.5}$ sampled in an urban environment in Atlanta, Georgia, USA, has a DTT activity in the range of $10-70 \mathrm{pmol} \mathrm{min}^{-1} \mu \mathrm{g}^{-1}$. Assuming an integration time of 20 min needed for the extraction of PM in this work, this value corresponds to $(1-8) \times 10^{14} \mu \mathrm{g}^{-1}$ of DTT molecules consumed. Charrier et al. (2012) also reported that $\mathrm{PM}_{2.5}$ sampled in an urban environment in Fresno, California, USA, has a DTT activity of $27-61 \mathrm{pmol} \mathrm{min}^{-1} \mu \mathrm{g}^{-1}$, corresponding to (2-7) $\times 10^{14}{\mu \mathrm{g}^{-1}}^{-1}$ of DTT molecules consumed in $20 \mathrm{~min}$. Assuming that the consumption of one DTT molecule would correspond to the generation of one ROS molecule (e.g., $\mathrm{H}_{2} \mathrm{O}_{2}$ ), these values are about a few orders of magnitude higher than concentrations of radical forms of ROS measured in this study. This is reasonable as $\mathrm{H}_{2} \mathrm{O}_{2}$ is closed shell and much more stable than open-shell radical forms of ROS.

\subsection{ROS formation mechanism}

It has been shown that semiquinones and reduced transition metals including, $\mathrm{Fe}(\mathrm{II})$ and $\mathrm{Cu}(\mathrm{I})$, can react with $\mathrm{O}_{2}$ to form $\mathrm{O}_{2}^{-}$, which can be further converted into $\mathrm{H}_{2} \mathrm{O}_{2}$ (Gehling et al., 2014; Fang et al., 2016). Fenton-like reactions of $\mathrm{H}_{2} \mathrm{O}_{2}$ with $\mathrm{Fe}(\mathrm{II})$ or $\mathrm{Cu}(\mathrm{I})$ can lead to the formation of $\mathrm{OH}$ radicals (Winterbourn, 2008; Pöschl and Shiraiwa, 2015). OH radicals can also be generated by the decomposition of organic hydroperoxides $(\mathrm{ROOH})$ contained in SOA, yielding RO radicals (Tong et al., 2016). Several studies have reported a metal-independent decomposition of hydroperoxides and organic hydroperoxides driven by substituted quinones producing RO radicals (Sanchez-Cruz et al., 2014; Huang et al., 2015). The presence of $\mathrm{Fe}(\mathrm{II})$ or quinones is suggested to enhance ROOH decomposition and the formation of RO and OH radicals (Zhu et al., 2007a, b, 2009; Sanchez-Cruz et al., 2014). Organic peroxides (ROOR) do not yield $\mathrm{OH}$ and RO radicals even in the presence of iron ions (Tong et al., 2016).

Based on these previous studies and considering that ambient particles may contain quinones, organic hydroperoxides and transition metals, the observed ROS formation may 

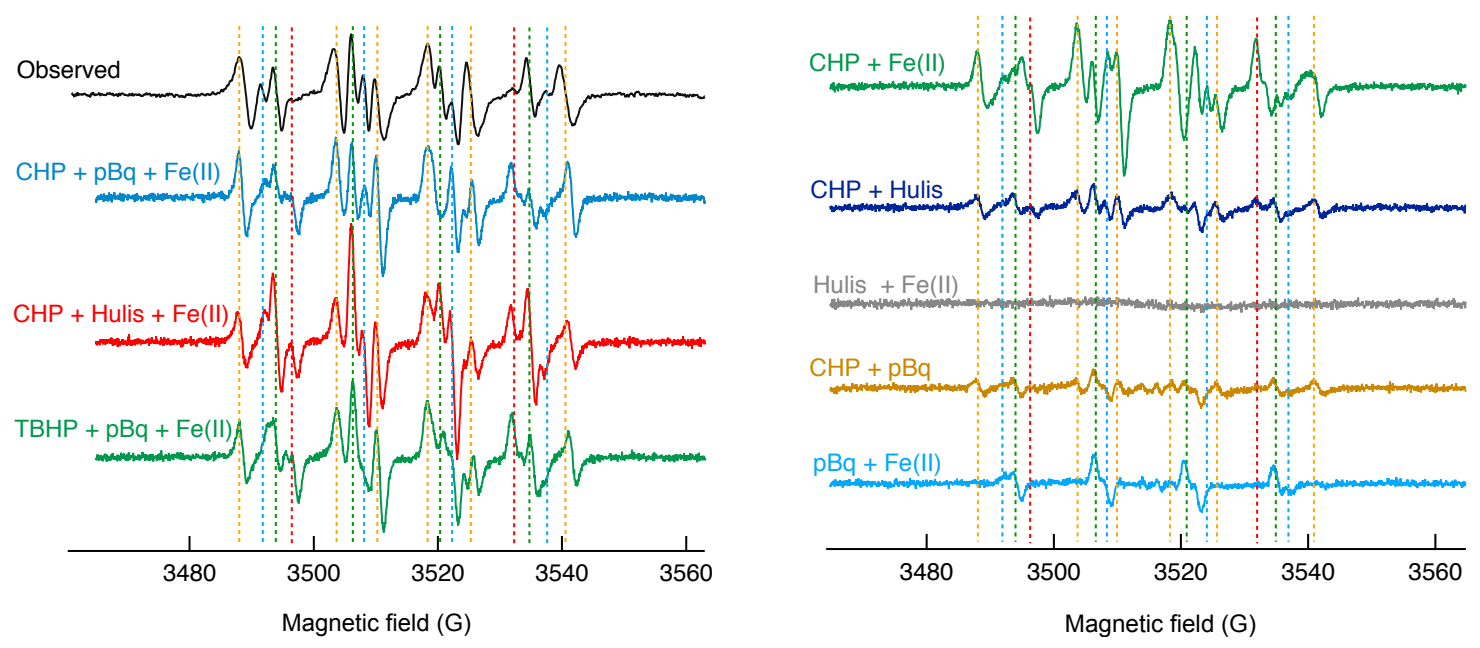

Figure 6. Electron paramagnetic resonance (EPR) spectra of atmospheric aerosol impactor sample with particle diameters in the range of 180-320 nm (lower to upper cut-off) extracted with water and BMPO (black) and of aqueous substance mixtures with the following ingredients: cumene hydroperoxide (CHP), p-benzoquinone (pBq) and Fe(II) (light blue) and t-butyl hydroperoxide (TBHP). The dashed vertical lines indicate the main peaks of BMPO adducts with $\mathrm{O}_{2}^{-}$(red), $\mathrm{OH}$ (green), carbon- (light blown) and oxygen-centered organic radicals (light blue).

be caused by interactions of these chemical components. To further investigate this aspect, mixtures of organic hydroperoxides, quinones and $\mathrm{Fe}(\mathrm{II})$ were analyzed by EPR and liquid chromatography mass spectrometry (LC-MS). Two standard organic hydroperoxides, cumene hydroperoxide and tert-butyl hydroperoxide, were used. For quinones, pbenzoquinone and humic-like substances are used, as humiclike substance (HULIS) are known to contain substantial amounts of quinones (Verma et al., 2015b).

Figure 6 shows the comparison of EPR spectra of ambient particles with a diameter of 180-320 nm (black) sampled on 26 June 2015 (same as shown in Fig. 4) and the above mixtures of organic compounds. Panel a includes EPR spectra of mixtures of all three different components $(\mathrm{ROOH}$, quinone, metal) and panel $b$ presents mixtures of two different components. All three of the organic mixtures in panel a resemble the EPR spectrum of ambient particles by reproducing almost all of the peaks. In particular, the EPR spectrum of the mixture containing cumene hydroperoxide, humic acid and $\mathrm{Fe}$ (II) closely overlaps with the ambient particle EPR spectrum. Similarity of spectra between p-benzoquinone and HULIS suggests that the chemical nature of quinones and HULIS is very similar. Note that peaks related to the BMPO$\mathrm{OOH}$ adduct at $3497 \mathrm{G}$ and at $3530 \mathrm{G}$ are more prominent in standard organic mixtures compared to ambient particles. This may be due to the relatively short lifetime of BMPOOOH of $\sim 23 \mathrm{~min}$ (Zhao et al., 2001), which is comparable to the extraction and mixing time of BMPO with the atmospheric particles (21-28 min), during which BMPO-OOH may decay. The trapped radicals have been further characterized by LC-MS, confirming the presence of $\mathrm{OH}$ and semiquinone radicals as well as carbon- and oxygen-centered organic radicals, as detailed in Appendix A and Figs. A1 and A2.

EPR spectra of mixtures containing two compounds in panel $b$ reproduce only a part of the observed peaks. These observations strongly suggest that the combination of these three chemical components play an important role in generating ROS species by atmospheric particles. The role of transition metals is crucial to enhance radical formation, most likely via Fenton-like reactions (Tong et al., 2016) and by participating in redox-cycling of quinones (Khachatryan and Dellinger, 2011), as intensities of EPR spectra without Fe(II) (CHP + HULIS, dark blue; CHP $+\mathrm{pBq}$, orange) are small. Carbon-centered radicals may have multiple sources, such as the decomposition of the BMPO-OR adduct by scission of the carbon in $\beta$ position, yielding for example $\mathrm{CH}_{3}$ radicals (Zhu et al., 2007b; Huang et al., 2015), as detected by LC-MS (Fig. A2). They may also be generated by secondary reactions of non-trapped $\mathrm{OH}$ radicals with water-soluble organic compounds.

SOA particles, which may contain large amounts of organic hydroperoxides, account for a major fraction in $\mathrm{PM}_{1}$ (Jimenez et al., 2009). SOA compounds may also coat coarse particles such as biological particles (Pöhlker et al., 2012). As shown in Fig. 2, semiquinones are mostly contained in submicron particles but not in coarse particles. Thus, the release of a variety of ROS species is most likely due to the interactions of organic hydroperoxides, semiquinones and transition metal ions, whereas the dominance of $\mathrm{OH}$ radicals in coarse particles may be due to the decomposition of organic hydroperoxides in the absence of semiquinones. 


\section{Conclusions and implications}

In this study particle-associated environmentally persistent free radicals (EPFR) and radical forms of ROS have been quantified using electron paramagnetic resonance (EPR) spectroscopy. Average EPFR concentrations were measured

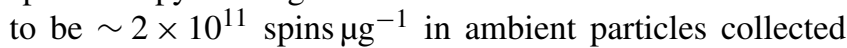
in Mainz, Germany, in May-June 2015. The chemical identity of EPFR is likely to be semiquinone radicals based on the $g$ factors observed by EPR spectroscopy. We found that particles with different sizes had different radical contents and particles with a diameter of $100-180 \mathrm{~nm}$ had the highest abundance of EPFR, whereas coarse particles did not contain EPFR. This is consistent with the size distribution of combustion particles, such as soot and humic-like substances (HULIS), which may contain substantial amounts of EPFR.

Reactive oxygen species (ROS) are formed upon extraction of particles into water. Particles with the diameter of $100-180 \mathrm{~nm}$ have released the highest ROS concentrations of $2.7( \pm 0.2) \times 10^{11}$ spins $\mu g^{-1}$. By deconvolution of the obtained EPR spectra, four types of radicals, including $\mathrm{OH}$, $\mathrm{O}_{2}^{-}$, carbon-centered and oxygen-centered organic radicals were quantified. The relative amounts of $\mathrm{OH}, \mathrm{O}_{2}^{-}, \mathrm{C}$-centered and $\mathrm{O}$-centered organic radicals in submicron particles were found to be $\sim 11-31, \sim 2-8, \sim 41-72$ and $\sim 0-25 \%$, respectively, depending on the particle size. $\mathrm{OH}$ was the dominant species for coarse particles with a diameter larger than $1 \mu \mathrm{m}$. We suggest that the formation of these ROS species is due to the decomposition of organic hydroperoxides, which are a major component in SOA, interacting with semiquinones contained in soot or HULIS. ROS formation by Fenton-like reactions can be enhanced in the presence of iron ions.

These findings have significant implications for the chemical processing of organic aerosols in deliquesced particles and cloud water. The released $\mathrm{OH}$ radicals within particles or cloud droplets can oxidize other organic compounds, producing low-volatility products, including organic acids, peroxides and oligomers (Lim et al., 2010; McNeill et al., 2012; Ervens, 2015; Herrmann et al., 2015). Autoxidation in the condensed phase might be triggered by $\mathrm{OH}$ radicals forming highly oxidized compounds (Shiraiwa et al., 2014; Tong et al., 2016). High aqueous oxidant levels may cause fragmen- tation of organic compounds, resulting in an increased loss of carbon from the condensed phase (Daumit et al., 2016). The formed carbon- and oxygen-centered organic radicals are also expected to enhance chemical aging by participating in particle-phase chemistry involving aldehydes, carbonyls and organic peroxides (Ziemann and Atkinson, 2012), although the exact role and impact of formed organic radicals are still unclear and subject to further studies.

Previous studies have shown that redox-active components such as transition metals and quinones can induce ROS formation in surrogate lung lining fluid upon interactions with antioxidants (Charrier and Anastasio, 2011; Charrier et al., 2014). This study also implies that ROS can be formed in lung lining fluid upon inhalation and respiratory deposition of atmospheric aerosol particles. Even though some fractions of ROS may be scavenged by antioxidants contained in lung lining fluid, excess concentrations of ROS, including $\mathrm{OH}$ radicals, superoxide and also, potentially, carbon- and oxygencentered organic radicals may cause oxidative stress to lung cells and tissues (Winterbourn, 2008; Pöschl and Shiraiwa, 2015; Tong et al., 2016). Recently, Lakey et al. (2016) have shown that fine particulate matter containing redox-active transition metals, quinones and secondary organic aerosols can increase ROS concentrations in the lung lining fluid to levels characteristic for respiratory diseases. ROS play a central role in chemical transformation of biomolecules, such as proteins and lipids, in lung fluid to form damage associated molecular patterns (DAMPs), which can trigger immune reactions causing inflammation through the tolling receptor radical cycle (Lucas and Maes, 2013). Due to the important implications of adverse aerosol health effects, further studies are warranted to characterize and quantify EPFR and ROS contained in atmospheric aerosol particles in various locations, including highly polluted regions such as East Asia and India.

\section{Data availability}

Data are available upon request by contacting M. Shiraiwa (m.shiraiwa@uci.edu). 


\section{Appendix A: LC-MS analysis of organic mixtures}

Two solutions of mixtures of standard organic hydroperoxides and quinones were analyzed by liquid chromatography mass spectrometry (LC-MS). Solution (1) was the mixture of $200 \mu \mathrm{L}$ of p-benzoquinone solution at a concentration of $0.2 \mathrm{~g} \mathrm{~L}^{-1}$ (Reagent grade, $\geq 98 \%$, SigmaAldrich) in water (trace SELECT ${ }^{\circledR}$ Ultra, ACS reagent, for ultratrace analysis, Sigma-Aldrich), $100 \mu \mathrm{L}$ of TertButyl hydroperoxide solution at a concentration of $8.9 \mathrm{~g} \mathrm{~L}^{-1}$ (Luperox ${ }^{\circledR}$ TBH70X, 70 wt. in $\% \mathrm{H}_{2} \mathrm{O}$, Sigma-Aldrich) in water, $2.5 \mu \mathrm{L}$ of Iron (II) sulfate heptahydrate solution at $0.3 \mathrm{~g} \mathrm{~L}^{-1}$ (reagentPlus ${ }^{\circledR}, \geq 99 \%$, Sigma-Aldrich) in water and $1 \mathrm{mg}$ of 5-tert-Butoxycarbonyl-5-methyl-1-pyrroline-Noxide (BMPO, high purity, Enzo Life Sciences, Inc.). Solution (2) was the same as solution (1) but without Iron (II) sulfate heptahydrate. These solutions were stirred with a vortex shaker (Heidolph Reax 1) for $5 \mathrm{~min}$.

These solutions were analyzed using a 1260 Infinity Bio-inert Quaternary LC system with a quaternary pump (G5611A), a HiP sampler (G5667A) and an electrospray ionization (ESI) source interfaced to a Q-TOF mass spectrometer (6540 UHD Accurate-Mass Q-TOF, Agilent Technologies). All modules were controlled by MassHunter software (B.06.01, Agilent). The LC column was a Zorbax ExtendC18 Rapid Resolution HT $(2.1 \times 50 \mathrm{~mm}, 1.8 \mu \mathrm{m})$ with a column temperature of $30^{\circ} \mathrm{C}$. The mobile phases were $3 \%$ $(v / v)$ acetonitrile (HPLC Gradient Grade, Fisher Chemical) in water with formic acid $(0.1 \% v / v$, LC-MS Chromasolv, Sigma-Aldrich) (Eluent A) and $3 \%$ water in acetonitrile (Eluent B). The injection volume was $10 \mu \mathrm{L}$. The flow rate was $0.2 \mathrm{~mL} \mathrm{~min}^{-1}$ with a gradient program that starting with $3 \% \mathrm{~B}$ for $3 \mathrm{~min}$ followed by a $36 \mathrm{~min}$ steps that raised Eluent $\mathrm{B}$ to $60 \%$. Furthermore, Eluent B was increased to $80 \%$ at $40 \mathrm{~min}$ and returned to initial conditions within $0.1 \mathrm{~min}$, followed by column re-equilibration for $9.9 \mathrm{~min}$ before the next run.

The ESI-Q-TOF instrument was operated in the positive ionization mode (ESI+) with a gas temperature of $325^{\circ} \mathrm{C}$, 20 psig nebulizer, $4000 \mathrm{~V}$ capillary voltage and $90 \mathrm{~V}$ fragmental voltage. During the full spectrum MS mode, no collision energy was used in order to collect species as their molecular ions. During MS/MS analysis employed for the structure determination, the fragmentation of protonated ions was conducted using the target MS/MS mode with $20 \mathrm{~V}$ collision energy. Spectra were recorded over the mass range of $\mathrm{m} / \mathrm{z}$ 50-1000. Data analysis was performed using qualitative data analysis software (B.06.00, Agilent). Blank solutions without BMPO were also prepared and analyzed. Background signals were subtracted from the MS spectrum.
Figure A2 shows LC-MS/MS mass spectra of the products formed from the reaction of tert-butyl hydroperoxide, p-benzoquinone and BMPO in the presence of iron (solution 1). Very similar results were obtained for solutions in the absence of iron (solution 2). BMPO adducts with radicals $\cdot \mathrm{OH}, \cdot \mathrm{CH}_{3}$ and $\cdot \mathrm{OCH}_{3}$ were identified by $\mathrm{LC}$ MS/MS. As shown in Fig. A2a.1, it was observed that ions at $m / z, 160.0596,216.1221$ and 238.1020 were major ions formed in the positive mode. These protonated ions represent the $\left[\mathrm{BMPO}+\mathrm{OH}-\mathrm{C}_{4} \mathrm{H}_{8}+\mathrm{H}\right]^{+},[\mathrm{BMPO}+\mathrm{OH}+\mathrm{H}]^{+}$ and $[\mathrm{BMPO}+\mathrm{OH}+\mathrm{Na}+\mathrm{H}]^{+}$spin adducts, respectively. Figure A2a.2 displays the mass spectrum in the MS/MS mode for the fragmentation of the ion $m / z$ 216.1221. Results confirmed the loss of the t-butoxycarbonyl function $\left(-\mathrm{C}_{4} \mathrm{H}_{8}\right)$, which is a characteristic fragment of BMPO, to form the ion $m / z \quad 160.0585$. The observed ion fragment $m / z$ 114.0544, can be formed by the loss of $\mathrm{CH}_{2} \mathrm{O}_{2}$, as shown in Fig. A2a.3. In Fig. A2b.1, the spectrum showed the mass $m / z \quad 158.0804$ and 214.1431 that can be attributed to the $\left[\mathrm{BMPO}+\mathrm{CH}_{3}-\mathrm{C}_{4} \mathrm{H}_{8}+\mathrm{H}\right]^{+}$and $\left[\mathrm{BMPO}+\mathrm{CH}_{3}+\mathrm{H}\right]^{+}$, respectively. The most abundant fragment ion $(\mathrm{m} / z$ 158.0803) in the MS/MS mode confirmed the formation of BMPO $+\mathrm{CH}_{3}$ adduct, as shown in Fig. A2b.2. The peak $m / z 112.0752$ can be formed by the loss of $\mathrm{CH}_{2} \mathrm{O}_{2}$ (Fig. A2b.3). The spectrum in Fig. A2c.1 shows major peaks at $m / z 174.0752,230.1378$ and 252.1198, corresponding to $\left[\mathrm{BMPO}+\mathrm{OCH}_{3}-\mathrm{C}_{4} \mathrm{H}_{8}+\mathrm{H}\right]^{+},\left[\mathrm{BMPO}+\mathrm{OCH}_{3}+\mathrm{H}\right]^{+}$and $\left[\mathrm{BMPO}+\mathrm{OCH}_{3}+\mathrm{Na}+\mathrm{H}\right]^{+}$, respectively. The formation of $\mathrm{BMPO}-\mathrm{OCH}_{3}$ was confirmed in MS/MS by the loss of the t-butoxycarbonyl functional group of BMPO to form the ion at $m / z 174.0749$ (panels c.2 and c.3).

In addition, the radicals $\mathrm{C}_{6} \mathrm{H}_{5} \mathrm{O}_{2} \cdot$ or $\cdot \mathrm{C}_{6} \mathrm{H}_{5} \mathrm{O}_{2}$ and $\mathrm{C}_{6} \mathrm{H}_{9} \mathrm{O}_{2} \cdot$ or $\cdot \mathrm{C}_{6} \mathrm{H}_{9} \mathrm{O}_{2}$ were detected, although it was not possible to determine whether the chemical structure represented carbon- or oxygen-centered organic radicals using the applied method. Figure A3a.1 shows the formation of protonated ions $\left[\mathrm{BMPO}+\mathrm{C}_{6} \mathrm{H}_{5} \mathrm{O}_{2}+\mathrm{H}\right]^{+}$ and $\left[\mathrm{BMPO}+\mathrm{C}_{6} \mathrm{H}_{5} \mathrm{O}_{2}+\mathrm{Na}+\mathrm{H}\right]^{+}$with $m / z \quad 308.1475$ and 330.1298, respectively. The fragmentation in the MS/MS mode confirms the formation of BMPO $+\mathrm{C}_{6} \mathrm{H}_{5} \mathrm{O}_{2}$ $(\mathrm{m} / \mathrm{z} 252.0855)$ that corresponds to the loss of the characteristic t-butoxycarbonyl function as shown in Fig. A3a.2. The ion fragment observed $m / z$ 128.0702, can be formed by the loss of $\mathrm{C}_{5} \mathrm{O}_{4}$ (Fig. A3a.3). Figure A3b.1 shows the ion $m / z$ 312.1789, which can be attributed to the $\mathrm{BMPO}+\mathrm{C}_{6} \mathrm{H}_{9} \mathrm{O}_{2}$ spin adduct. Figure A3b.2 suggests that the fragmentation of $m / z 312.1789$ to 256.1166 by the loss of $-\mathrm{C}_{4} \mathrm{H}_{8}$ (Fig. A3b.3). 

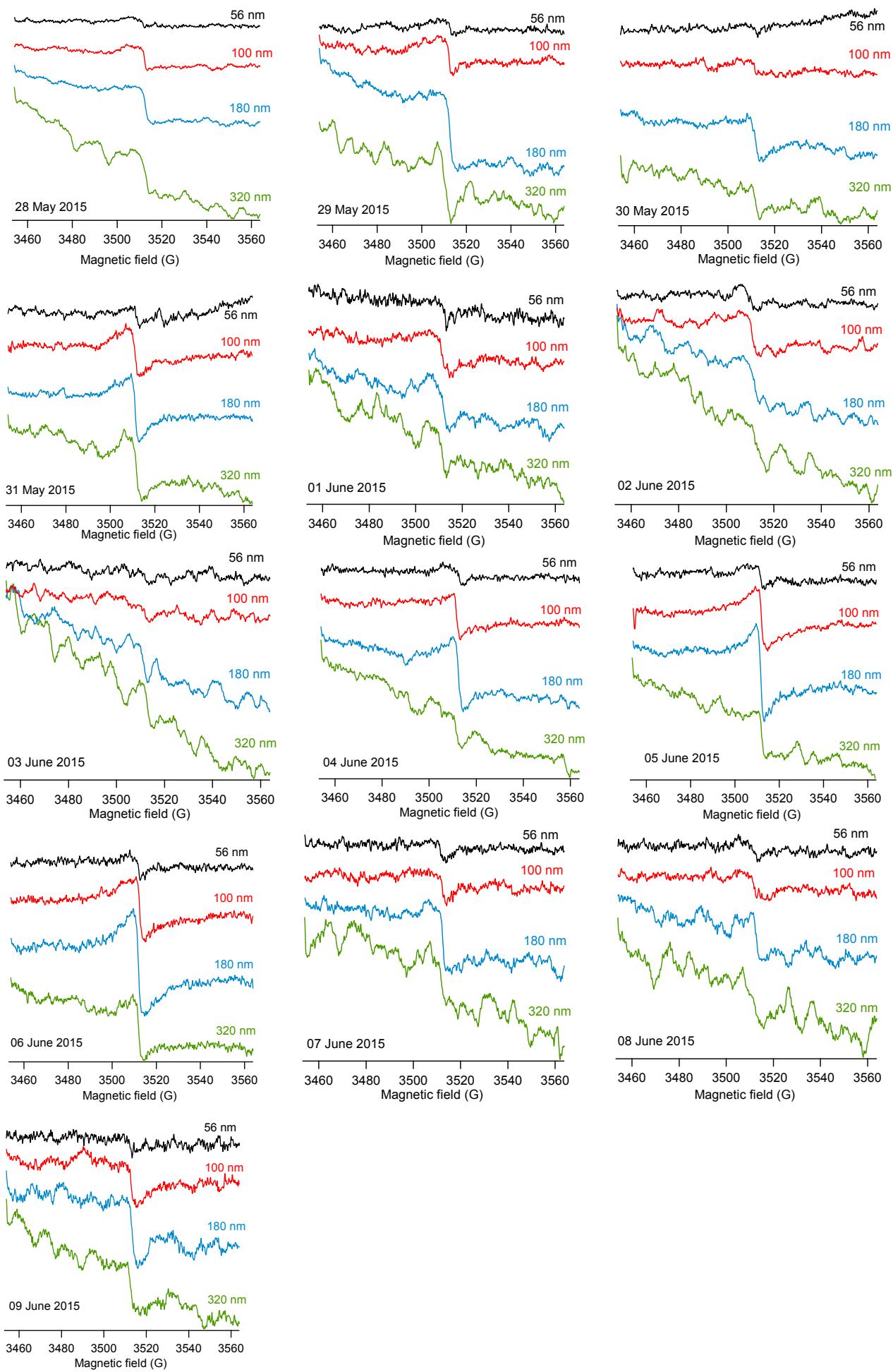

Figure A1. EPR spectra of atmospheric aerosol impactor samples with lower cut-off diameters of $56 \mathrm{~nm}$ (black), $100 \mathrm{~nm}$ (red), $180 \mathrm{~nm}$ (light blue) and $320 \mathrm{~nm}$ (green) for the measurement period during 28 May-9 June 2015. 


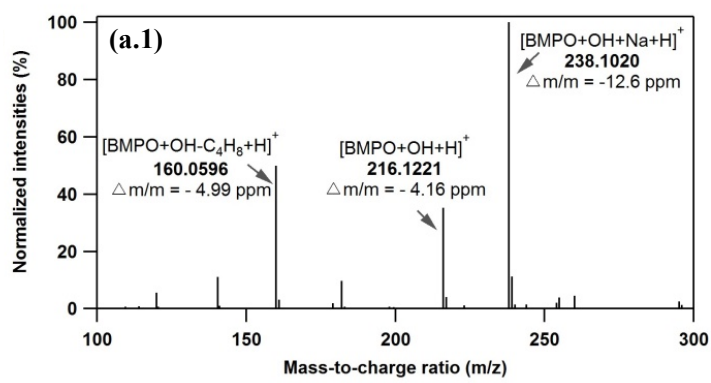

(a.2)

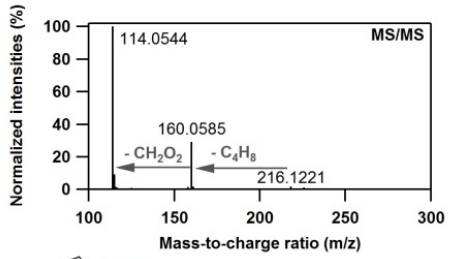

(a.3)
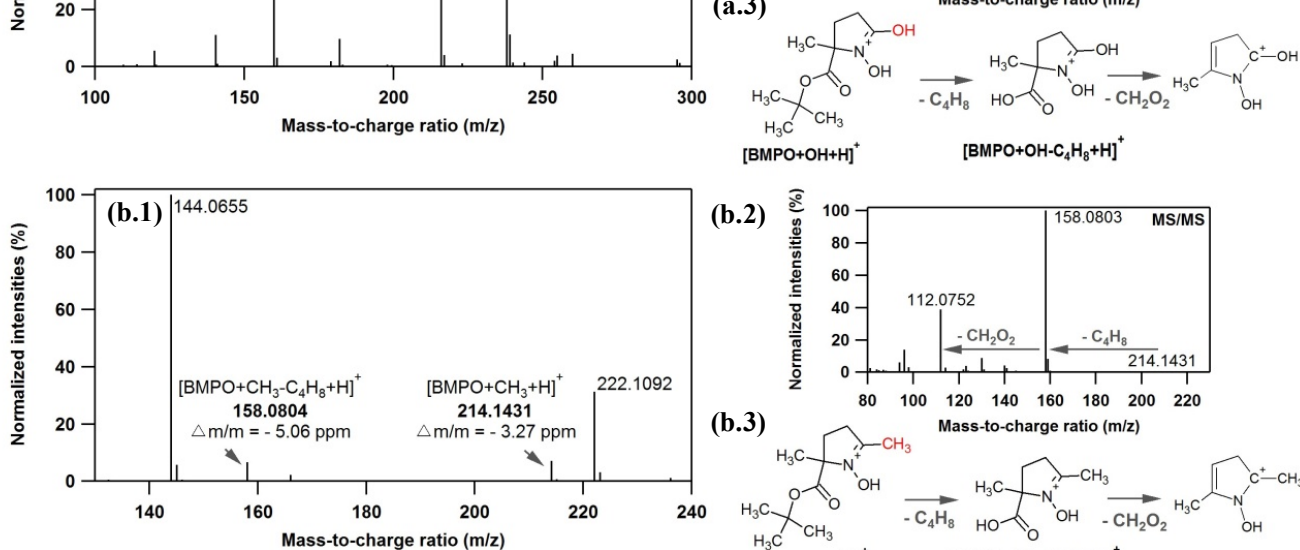

(b.2)

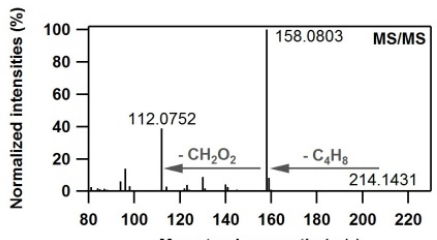

(b.3)
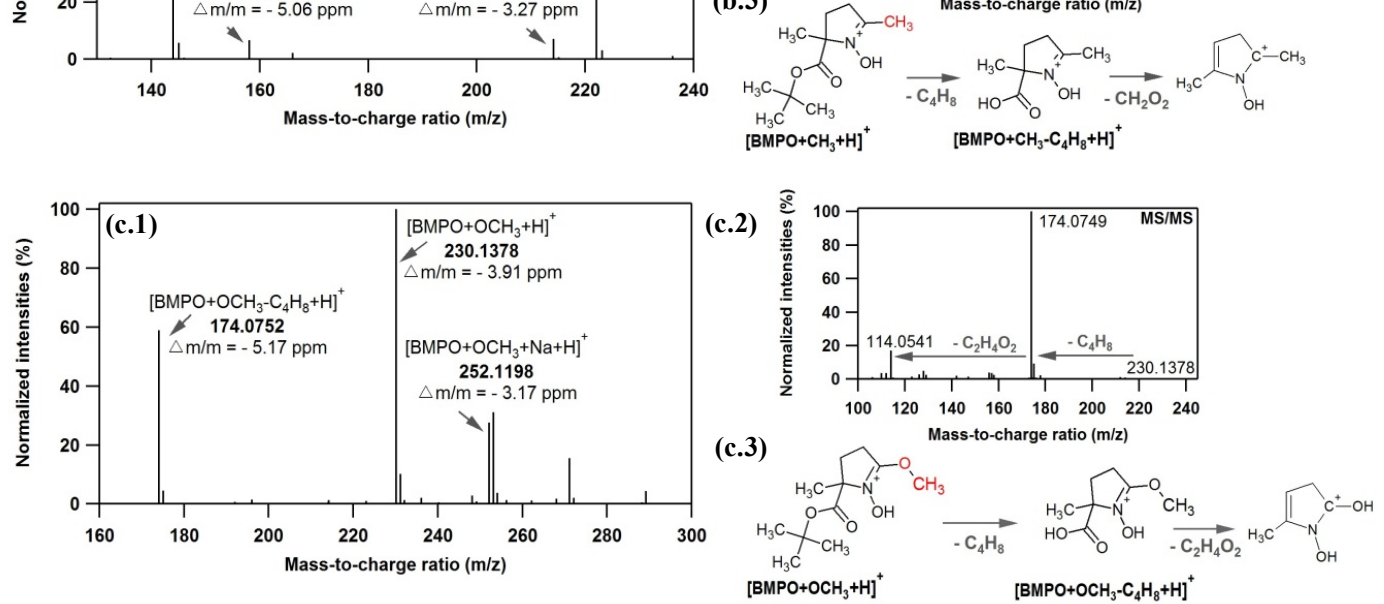

Figure A2. Mass spectra obtained with LC-MS/MS in the positive ionization mode from the mixture of tert-butyl hydroperoxide, p-benzoquinone and BMPO in the presence of iron (solution 1). MS spectra of (a.1) $\mathrm{BMPO}+\mathrm{OH},(\mathbf{b . 1}) \mathrm{BMPO}+\mathrm{CH}_{3}$ and (c.1) $\mathrm{BMPO}+\mathrm{OCH}_{3}$. MS/MS spectra of (a.2) $\mathrm{BMPO}+\mathrm{OH},(\mathbf{b} .2) \mathrm{BMPO}+\mathrm{CH}_{3}$ and (c.2) $\mathrm{BMPO}+\mathrm{OCH}_{3}$. Proposed fragmentation pathways of (a.3) $\mathrm{BMPO}+\mathrm{OH},(\mathbf{b . 3}) \mathrm{BMPO}+\mathrm{CH}_{3}$ and (c.3) $\mathrm{BMPO}+\mathrm{OCH}_{3}$. 


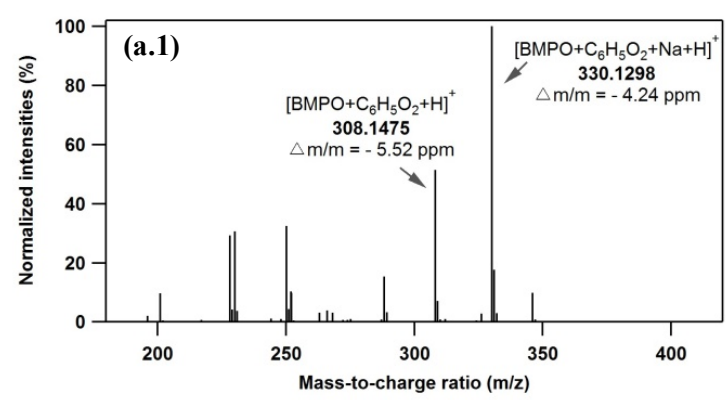

(a.2)

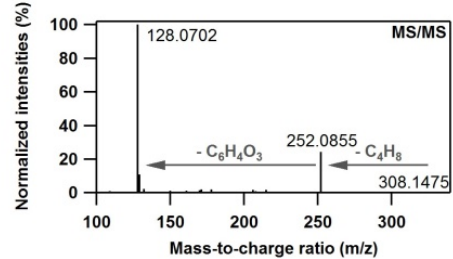

(a.3)
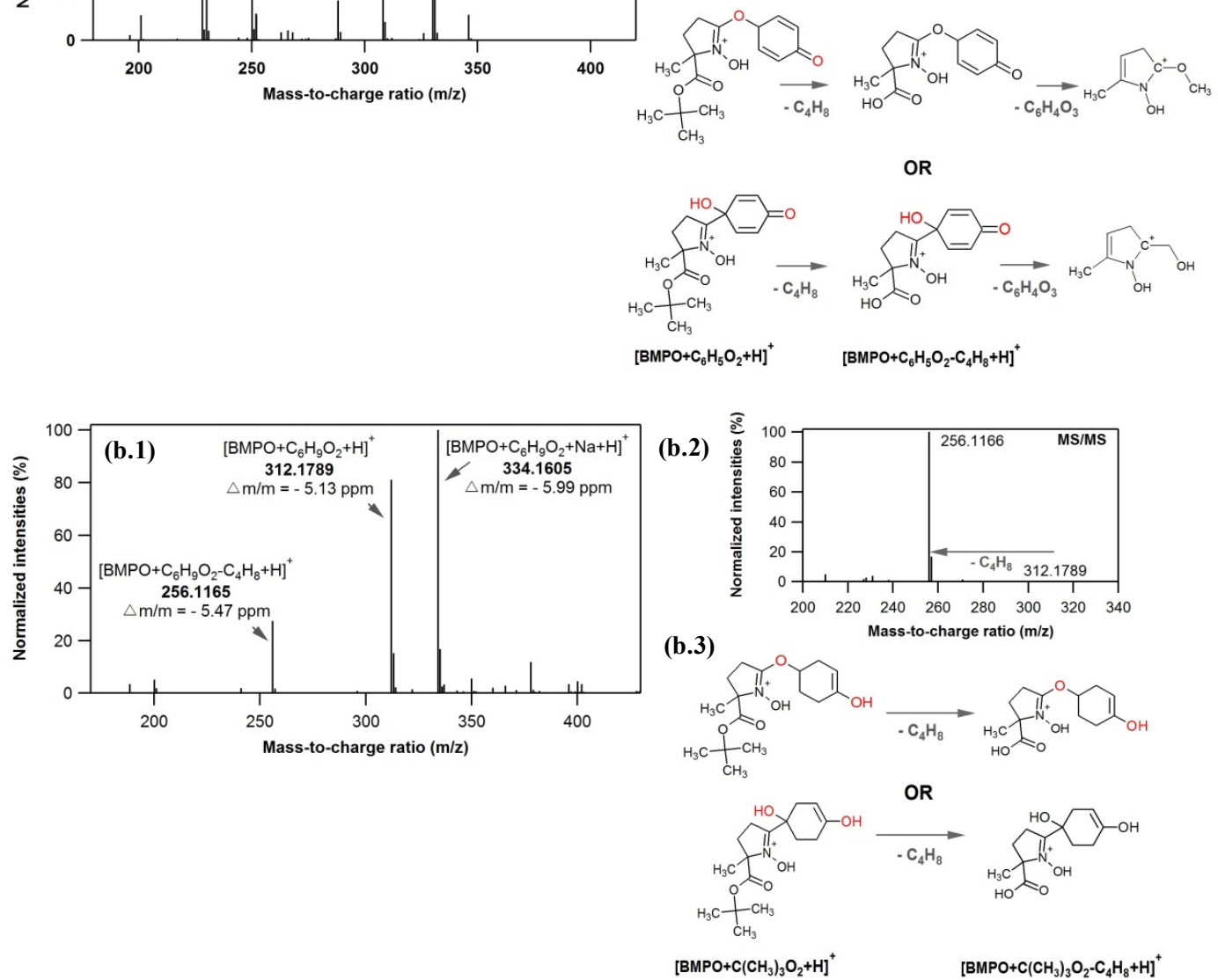

Figure A3. Mass spectra obtained with LC-MS/MS in the positive ionization mode for solution (1). MS spectra of (a.1) BMPO $+\mathrm{C}_{6} \mathrm{H}_{5} \mathrm{O}_{2}$ and (b.1) BMPO $+\mathrm{C}_{6} \mathrm{H}_{9} \mathrm{O}_{2}$. MS/MS spectra of (a.2) BMPO $+\mathrm{C}_{6} \mathrm{H}_{5} \mathrm{O}_{2}$ and (b.2) BMPO $+\mathrm{C}_{6} \mathrm{H}_{9} \mathrm{O}_{2}$. Proposed fragmentation pathways of (a.3) $\mathrm{BMPO}+\mathrm{C}_{6} \mathrm{H}_{5} \mathrm{O}_{2}$ and (b.3) $\mathrm{BMPO}+\mathrm{C}_{6} \mathrm{H}_{9} \mathrm{O}_{2}$. 
Acknowledgements. This study is funded by the Max Planck Society. We thank Christopher Kampf and Fobang Liu for helping with LC-MS analysis and Pascale Lakey for helpful comments.

The article processing charges for this open-access publication were covered by the Max Planck Society.

Edited by: A. Kiendler-Scharr

Reviewed by: four anonymous referees

\section{References}

Abbas, K., Hardy, M., Poulhès, F., Karoui, H., Tordo, P., Ouari, O., and Peyrot, F.: Detection of superoxide production in stimulated and unstimulated living cells using new cyclic nitrone spin traps, Free Radical Biol. Med., 71, 281-290, 2014.

Badali, K. M., Zhou, S., Aljawhary, D., Antiñolo, M., Chen, W. J., Lok, A., Mungall, E., Wong, J. P. S., Zhao, R., and Abbatt, J. P. D.: Formation of hydroxyl radicals from photolysis of secondary organic aerosol material, Atmos. Chem. Phys., 15, 7831-7840, doi:10.5194/acp-15-7831-2015, 2015.

Bahrle, C., Nick, T. U., Bennati, M., Jeschke, G., and Vogel, F.: High-Field Electron Paramagnetic Resonance and Density Functional Theory Study of Stable Organic Radicals in Lignin: Influence of the Extraction Process, Botanical Origin, and Protonation Reactions on the Radical g Tensor, J. Phys. Chem. A, 119, 64756482, 2015.

Bateman, A. P., Belassein, H., and Martin, S. T.: Impactor Apparatus for the Study of Particle Rebound: Relative Humidity and Capillary Forces, Aerosol Sci. Technol., 48, 42-52, 2014.

Berkemeier, T., Steimer, S., Krieger, U. K., Peter, T., Pöschl, U., Ammann, M., and Shiraiwa, M.: Ozone uptake on glassy, semisolid and liquid organic matter and the role of reactive oxygen intermediates in atmospheric aerosol chemistry, Phys. Chem. Chem. Phys., 18, 12662-12674, 2016.

Birben, E., Sahiner, U. M., Sackesen, C., Erzurum, S., and Kalayci, O.: Oxidative Stress and Antioxidant Defense, World Allergy Organization Journal, 5, 1-11, 2012.

Bond, T. C., Doherty, S. J., Fahey, D. W., Forster, P. M., Berntsen, T., DeAngelo, B. J., Flanner, M. G., Ghan, S., Karcher, B., Koch, D., Kinne, S., Kondo, Y., Quinn, P. K., Sarofim, M. C., Schultz, M. G., Schulz, M., Venkataraman, C., Zhang, H., Zhang, S., Bellouin, N., Guttikunda, S. K., Hopke, P. K., Jacobson, M. Z., Kaiser, J. W., Klimont, Z., Lohmann, U., Schwarz, J. P., Shindell, D., Storelvmo, T., Warren, S. G., and Zender, C. S.: Bounding the role of black carbon in the climate system: A scientific assessment, J. Geophys. Res.-Atmos., 118, 5380-5552, 2013.

Borrowman, C. K., Zhou, S., Burrow, T. E., and Abbatt, J. P.: Formation of environmentally persistent free radicals from the heterogeneous reaction of ozone and polycyclic aromatic compounds, Phys. Chem. Chem. Phys., 18, 205-212, 2015.

Charrier, J. G. and Anastasio, C.: Impacts of antioxidants on hydroxyl radical production from individual and mixed transition metals in a surrogate lung fluid, Atmos. Environ., 45, 7555-7562, 2011.

Charrier, J. G., McFall, A. S., Richards-Henderson, N. K., and Anastasio, C.: Hydrogen Peroxide Formation in a Surrogate
Lung Fluid by Transition Metals and Quinones Present in Particulate Matter, Environ. Sci. Technol., 48, 7010-7017, 2014.

Chen, X. and Hopke, P. K.: A chamber study of secondary organic aerosol formation by limonene ozonolysis, Indoor Air, 20, 320328, 2010.

Chen, X., Hopke, P. K., and Carter, W. P.: Secondary organic aerosol from ozonolysis of biogenic volatile organic compounds: chamber studies of particle and reactive oxygen species formation, Environ. Sci. Technol., 45, 276-282, 2011.

Cho, A. K., Sioutas, C., Miguel, A. H., Kumagai, Y., Schmitz, D. A., Singh, M., Eiguren-Fernandez, A., and Froines, J. R.: Redox activity of airborne particulate matter at different sites in the Los Angeles Basin, Environ. Res., 99, 40-47, 2005.

Crounse, J. D., Nielsen, L. B., Jørgensen, S., Kjaergaard, H. G., and Wennberg, P. O.: Autoxidation of organic compounds in the atmosphere, J. Phys. Chem. Lett., 4, 3513-3520, 2013.

Daumit, K. E., Carrasquillo, A. J., Sugrue, R. A., and Kroll, J. H.: Effects of Condensed-Phase Oxidants on Secondary Organic Aerosol Formation, J. Phys. Chem. A, 120, 1386-1394, 2016.

Dellinger, B., Pryor, W. A., Cueto, R., Squadrito, G. L., Hegde, V., and Deutsch, W. A.: Role of Free Radicals in the Toxicity of Airborne Fine Particulate Matter, Chem. Res. Toxicol., 14, 13711377, 2001.

Dellinger, B., Loninicki, S., Khachatryan, L., Maskos, Z., Hall, R. W., Adounkpe, J., McFerrin, C., and Truong, H.: Formation and stabilization of persistent free radicals, Proc. Combust. Inst., 31, 521-528, 2007.

Docherty, K. S., Wu, W., Lim, Y. B., and Ziemann, P. J.: Contributions of Organic Peroxides to Secondary Aerosol Formed from Reactions of Monoterpenes with $\mathrm{O}_{3}$, Environ. Sci. Technol., 39, 4049-4059, 2005.

Dou, J., Lin, P., Kuang, B.-Y., and Yu, J. Z.: Reactive Oxygen Species Production Mediated by Humic-like Substances in Atmospheric Aerosols: Enhancement Effects by Pyridine, Imidazole, and Their Derivatives, Environ. Sci. Technol., 49, 64576465, 2015.

Ehn, M., Thornton, J. A., Kleist, E., Sipila, M., Junninen, H., Pullinen, I., Springer, M., Rubach, F., Tillmann, R., Lee, B., LopezHilfiker, F., Andres, S., Acir, I.-H., Rissanen, M., Jokinen, T., Schobesberger, S., Kangasluoma, J., Kontkanen, J., Nieminen, T., Kurten, T., Nielsen, L. B., Jorgensen, S., Kjaergaard, H. G., Canagaratna, M., Dal Maso, M., Berndt, T., Petaja, T., Wahner, A., Kerminen, V.-M., Kulmala, M., Worsnop, D. R., Wildt, J., and Mentel, T. F.: A large source of low-volatility secondary organic aerosol, Nature, 506, 476-479, 2014.

Enami, S., Sakamoto, Y., and Colussi, A. J.: Fenton chemistry at aqueous interfaces, P. Natl. Acad. Sci. USA, 111, 623-628, 2014.

Epstein, S. A., Blair, S. L., and Nizkorodov, S. A.: Direct photolysis of $\alpha$-pinene ozonolysis secondary organic aerosol: effect on particle mass and peroxide content, Environ. Sci. Technol., 48, 11251-11258, 2014.

Ervens, B.: Modeling the Processing of Aerosol and Trace Gases in Clouds and Fogs, Chem. Rev., 115, 4157-4198, 2015.

Fang, T., Verma, V., Bates, J. T., Abrams, J., Klein, M., Strickland, M. J., Sarnat, S. E., Chang, H. H., Mulholland, J. A., Tolbert, P. E., Russell, A. G., and Weber, R. J.: Oxidative potential of ambient water-soluble PM2.5 in the southeastern United States: contrasts in sources and health associations between ascorbic acid 
(AA) and dithiothreitol (DTT) assays, Atmos. Chem. Phys., 16, 3865-3879, doi:10.5194/acp-16-3865-2016, 2016.

Fuller, S. J., Wragg, F. P. H., Nutter, J., and Kalberer, M.: Comparison of on-line and off-line methods to quantify reactive oxygen species (ROS) in atmospheric aerosols, Atmos. Environ., 92, 97103,2014

Gehling, W. and Dellinger, B.: Environmentally Persistent Free Radicals and Their Lifetimes in $\mathrm{PM}_{2.5}$, Environ. Sci. Technol., 47, 8172-8178, 2013.

Gehling, W., Khachatryan, L., and Dellinger, B.: Hydroxyl radical generation from environmentally persistent free radicals (EPFRs) in PM 2.5, Environ. Sci. Technol., 48, 4266-4272, 2014.

Gomes, L., Bergametti, G., Dulac, F., and Ezat, U.: Assessing the actual size distribution of atmospheric aerosols collected with a cascade impactor, J. Aerosol Sci., 21, 47-59, 1990.

Gualtieri, M., Mantecca, P., Corvaja, V., Longhin, E., Perrone, M. G., Bolzacchini, E., and Camatini, M.: Winter fine particulate matter from Milan induces morphological and functional alterations in human pulmonary epithelial cells (A549), Toxicol. Lett., 188, 52-62, 2009.

Herrmann, H., Schaefer, T., Tilgner, A., Styler, S. A., Weller, C., Teich, M., and Otto, T.: Tropospheric Aqueous-Phase Chemistry: Kinetics, Mechanisms, and Its Coupling to a Changing Gas Phase, Chem. Rev., 115, 4259-4334, 2015.

Huang, C. H., Ren, F. R., Shan, G. Q., Qin, H., Mao, L., and Zhu, B. Z.: Molecular mechanism of metal-independent decomposition of organic hydroperoxides by halogenated quinoid carcinogens and the potential biological implications, Chem. Res. Toxicol., 28, 831-837, 2015.

Hung, H.-F. and Wang, C.-S.: Experimental determination of reactive oxygen species in Taipei aerosols, J. Aerosol Sci., 32, 1201$1211,2001$.

Jia, H., Nulaji, G., Gao, H., Wang, F., Zhu, Y., and Wang, C.: Formation and Stabilization of Environmentally Persistent Free Radicals Induced by the Interaction of Anthracene with Fe(III)Modified Clays, Environ. Sci. Technol., 50, 6310-6319, 2016.

Jimenez, J. L., Canagaratna, M. R., Donahue, N. M., Prevot, A. S. H., Zhang, Q., Kroll, J. H., DeCarlo, P. F., Allan, J. D., Coe, H., Ng, N. L., Aiken, A. C., Docherty, K. S., Ulbrich, I. M., Grieshop, A. P., Robinson, A. L., Duplissy, J., Smith, J. D., Wilson, K. R., Lanz, V. A., Hueglin, C., Sun, Y. L., Tian, J., Laaksonen, A., Raatikainen, T., Rautiainen, J., Vaattovaara, P., Ehn, M., Kulmala, M., Tomlinson, J. M., Collins, D. R., Cubison, M. J., Dunlea, E. J., Huffman, J. A., Onasch, T. B., Alfarra, M. R., Williams, P. I., Bower, K., Kondo, Y., Schneider, J., Drewnick, F., Borrmann, S., Weimer, S., Demerjian, K., Salcedo, D., Cottrell, L., Griffin, R., Takami, A., Miyoshi, T., Hatakeyama, S., Shimono, A., Sun, J. Y., Zhang, Y. M., Dzepina, K., Kimmel, J. R., Sueper, D., Jayne, J. T., Herndon, S. C., Trimborn, A. M., Williams, L. R., Wood, E. C., Middlebrook, A. M., Kolb, C. E., Baltensperger, U., and Worsnop, D. R.: Evolution of organic aerosols in the atmosphere, Science, 326, 1525-1529, 2009.

Kampf, C. J., Liu, F., Reinmuth-Selzle, K., Berkemeier, T., Meusel, H., Shiraiwa, M., and Pöschl, U.: Protein Cross-Linking and Oligomerization through Dityrosine Formation upon Exposure to Ozone, Environ. Sci. Technol., 49, 10859-10866, 2015.

Khachatryan, L. and Dellinger, B.: Environmentally Persistent Free Radicals (EPFRs)-2. Are Free Hydroxyl Radicals Generated in
Aqueous Solutions?, Environ. Sci. Technol., 45, 9232-9239, 2011.

Khachatryan, L., Vejerano, E., Lomnicki, S., and Dellinger, B.: Environmentally Persistent Free Radicals (EPFRs), 1. Generation of Reactive Oxygen Species in Aqueous Solutions, Environ. Sci. Technol., 45, 8559-8566, 2011.

Kumagai, Y., Arimoto, T., Shinyashiki, M., Shimojo, N., Nakai, Y., Yoshikawa, T., and Sagai, M.: Generation of reactive oxygen species during interaction of diesel exhaust particle components with NADPH-cytochrome P450 reductase and involvement of the bioactivation in the DNA damage, Free Radical Biol. Med., 22, 479-487, 1997.

Lakey, P. S. J., Berkemeier, T., Tong, H., Arangio, A. M., Lucas, K., Pöschl, U., and Shiraiwa, M.: Chemical exposureresponse relationship between air pollutants and reactive oxygen species in the human respiratory tract, Sci. Rep., 6, 32916, doi:10.1038/srep32916, 2016.

Lelieveld, J., Evans, J. S., Fnais, M., Giannadaki, D., and Pozzer, A.: The contribution of outdoor air pollution sources to premature mortality on a global scale, Nature, 525, 367-371, 2015.

Lim, Y. B., Tan, Y., Perri, M. J., Seitzinger, S. P., and Turpin, B. J.: Aqueous chemistry and its role in secondary organic aerosol (SOA) formation, Atmos. Chem. Phys., 10, 1052110539, doi:10.5194/acp-10-10521-2010, 2010.

Lin, P. and Yu, J. Z.: Generation of Reactive Oxygen Species Mediated by Humic-like Substances in Atmospheric Aerosols, Environ. Sci. Technol., 45, 10362-10368, 2011.

Lucas, K. and Maes, M.: Role of the Toll Like Receptor (TLR) Radical Cycle in Chronic Inflammation: Possible Treatments Targeting the TLR4 Pathway, Mol. Neurobiol., 48, 190-204, 2013.

McNeill, V. F., Woo, J. L., Kim, D. D., Schwier, A. N., Wannell, N. J., Sumner, A. J., and Barakat, J. M.: Aqueous-phase secondary organic aerosol and organosulfate formation in atmospheric aerosols: A modeling study, Environ. Sci. Technol., 46, 8075-8081, 2012.

McWhinney, R. D., Zhou, S., and Abbatt, J. P. D.: Naphthalene SOA: redox activity and naphthoquinone gas-particle partitioning, Atmos. Chem. Phys., 13, 9731-9744, doi:10.5194/acp-139731-2013, 2013.

Nel, A.: Air pollution-related illness: Effects of particles, Science, 308, 804-806, 2005.

Ouari, O., Hardy, M., Karoui, H., and Tordo, P.: Recent developments and applications of the coupled EPR/Spin trapping technique (EPR/ST), in: Electron Paramagnetic Resonance, The Royal Society of Chemistry, 221 1-40, 2011.

Pavlovic, J. and Hopke, P. K.: Detection of radical species formed by the ozonolysis of $\alpha$-pinene, J. Atmos. Chem., 66, 137-155, 2011.

Pöhlker, C., Wiedemann, K. T., Sinha, B., Shiraiwa, M., Gunthe, S. S., Smith, M., Su, H., Artaxo, P., Chen, Q., Cheng, Y., Elbert, W., Gilles, M. K., Kilcoyne, A. L. D., Moffet, R. C., Weigand, M., Martin, S. T., Pöschl, U., and Andreae, M. O.: Biogenic potassium salt particles as seeds for secondary organic aerosol in the Amazon, Science, 337, 1075-1078, 2012.

Pope, C. A. and Dockery, D. W.: Health effects of fine particulate air pollution: lines that connect, J. Air Waste Manag. Assoc., 56, 709-742, 2006.

Pöschl, U. and Shiraiwa, M.: Multiphase Chemistry at the Atmosphere-Biosphere Interface Influencing Climate and Pub- 
lic Health in the Anthropocene, Chem. Rev., 115, 4440-4475, 2015.

Pryor, W. A., Squadrito, G. L., and Friedman, M.: The cascade mechanism to explain ozone toxicity - The role of lipid ozonation products, Free Radical Biol. Med., 19, 935-941, 1995.

Reinmuth-Selzle, K., Ackaert, C., Kampf, C. J., Samonig, M., Shiraiwa, M., Kofler, S., Yang, H., Gadermaier, G., Brandstetter, H., Huber, C. G., Duschl, A., Oostingh, G. J., and Pöschl, U.: Nitration of the birch pollen allergen Bet v 1.0101: Efficiency and site-selectivity of liquid and gaseous nitrating agents, J. Proteome Res., 13, 1570-1577, 2014.

Saffari, A., Daher, N., Shafer, M. M., Schauer, J. J., and Sioutas, C.: Seasonal and spatial variation in reactive oxygen species activity of quasi-ultrafine particles (PM0.25) in the Los Angeles metropolitan area and its association with chemical composition, Atmos. Environ., 79, 566-575, 2013.

Saffari, A., Daher, N., Shafer, M. M., Schauer, J. J., and Sioutas, C.: Global perspective on the oxidative potential of airborne particulate matter: a synthesis of research findings, Environ. Sci. Technol., 48, 7576-7583, 2014.

Sanchez-Cruz, P., Santos, A., Diaz, S., and Alegria, A. E.: Metalindependent reduction of hydrogen peroxide by semiquinones, Chem. Res. Toxicol., 27, 1380-1386, 2014.

Shaltout, A. A., Boman, J., Shehadeh, Z. F., Al-Malawi, D.-A. R., Hemeda, O. M., and Morsy, M. M.: Spectroscopic investigation of $\mathrm{PM}_{2.5}$ collected at industrial, residential and traffic sites in Taif, Saudi Arabia, J. Aerosol Sci., 79, 97-108, 2015.

Shiraiwa, M., Sosedova, Y., Rouviere, A., Yang, H., Zhang, Y., Abbatt, J. P. D., Ammann, M., and Pöschl, U.: The role of longlived reactive oxygen intermediates in the reaction of ozone with aerosol particles, Nature Chem., 3, 291-295, 2011.

Shiraiwa, M., Selzle, K., Yang, H., Sosedova, Y., Ammann, M., and Pöschl, U.: Multiphase chemical kinetics of the nitration of aerosolized protein by ozone and nitrogen dioxide, Environ. Sci. Technol., 46, 6672-6680, 2012.

Shiraiwa, M., Berkemeier, T., Schilling-Fahnestock, K. A., Seinfeld, J. H., and Pöschl, U.: Molecular corridors and kinetic regimes in the multiphase chemical evolution of secondary organic aerosol, Atmos. Chem. Phys., 14, 8323-8341, doi:10.5194/acp-14-8323-2014, 2014.

Squadrito, G. L., Cueto, R., Dellinger, B., and Pryor, W. A.: Quinoid redox cycling as a mechanism for sustained free radical generation by inhaled airborne particulate matter, Free Radical Biol. Med., 31, 1132-1138, 2001.

Stoll, S. and Schweiger, A.: EasySpin, a comprehensive software package for spectral simulation and analysis in EPR, J. Magn. Reson., 178, 42-55, 2006.

Strak, M., Janssen, N. A., Godri, K. J., Gosens, I., Mudway, I. S., Cassee, F. R., Lebret, E., Kelly, F. J., Harrison, R. M., Brunekreef, B., Steenhof, M., and Hoek, G.: Respiratory health effects of airborne particulate matter: the role of particle size, composition, and oxidative potential-the RAPTES project, Environ. Health Persp., 120, 1183-1189, 2012.

Sueishi, Y., Kamogawa, E., Nakamura, H., Ukai, M., Kunieda, M., Okada, T., Shimmei, M., and Kotake, Y.: Kinetic Evaluation of Spin Trapping Rate Constants of New CYPMPO-type Spin Traps for Superoxide and Other Free Radicals, Z. Phys. Chem., 229, 317-326, 2015.
Tong, H., Arangio, A. M., Lakey, P. S. J., Berkemeier, T., Liu, F., Kampf, C. J., Brune, W. H., Pöschl, U., and Shiraiwa, M.: Hydroxyl radicals from secondary organic aerosol decomposition in water, Atmos. Chem. Phys., 16, 1761-1771, doi:10.5194/acp-161761-2016, 2016.

Truong, H., Lomnicki, S., and Dellinger, B.: Potential for Misidentification of Environmentally Persistent Free Radicals as Molecular Pollutants in Particulate Matter, Environ. Sci. Technol., 44, 1933-1939, 2010.

Vejerano, E., Lomnicki, S., and Dellinger, B.: Formation and stabilization of combustion-generated environmentally persistent free radicals on an $\mathrm{Fe}(\mathrm{III})_{2} \mathrm{O}_{3} /$ silica surface, Environ. Sci. Technol., 45, 589-594, 2011.

Venkatachari, P., Hopke, P. K., Grover, B. D., and Eatough, D. J.: Measurement of Particle-Bound Reactive Oxygen Species in Rubidoux Aerosols, J. Atmos. Chem., 50, 49-58, 2005.

Venkatachari, P., Hopke, P. K., Brune, W. H., Ren, X., Lesher, R., Mao, J., and Mitchell, M.: Characterization of Wintertime Reactive Oxygen Species Concentrations in Flushing, New York, Aerosol Sci. Tech., 41, 97-111, 2007.

Verma, V., Fang, T., Xu, L., Peltier, R. E., Russell, A. G., Ng, N. L., and Weber, R. J.: Organic Aerosols Associated with the Generation of Reactive Oxygen Species (ROS) by Water-Soluble $\mathrm{PM}_{2.5}$, Environ. Sci. Technol., 49, 4646-4656, 2015 a.

Verma, V., Wang, Y., El-Afifi, R., Fang, T., Rowland, J., Russell, A. G., and Weber, R. J.: Fractionating ambient humic-like substances (HULIS) for their reactive oxygen species activity - Assessing the importance of quinones and atmospheric aging, Atmos. Environ., 120, 351-359, 2015 b.

Wang, D., Pakbin, P., Shafer, M. M., Antkiewicz, D., Schauer, J. J., and Sioutas, C.: Macrophage reactive oxygen species activity of water-soluble and water-insoluble fractions of ambient coarse, $\mathrm{PM}_{2.5}$ and ultrafine particulate matter (PM) in Los Angeles, Atmos. Environ., 77, 301-310, 2013.

Wang, Y., Kim, H., and Paulson, S. E.: Hydrogen peroxide generation from alpha- and beta-pinene and toluene secondary organic aerosols, Atmos. Environ., 45, 3149-3156, 2011.

Wang, Y., Arellanes, C., and Paulson, S. E.: Hydrogen Peroxide Associated with Ambient Fine-Mode, Diesel, and Biodiesel Aerosol Particles in Southern California, Aerosol Sci. Technol., 46, 394-402, 2012.

West, J. J., Cohen, A., Dentener, F., Brunekreef, B., Zhu, T., Armstrong, B., Bell, M. L., Brauer, M., Carmichael, G., Costa, D. L., Dockery, D. W., Kleeman, M., Krzyzanowski, M., Künzli, N., Liousse, C., Lung, S.-C. C., Martin, R. V., Pöschl, U., Pope, C. A., Roberts, J. M., Russell, A. G., and Wiedinmyer, C.: "What We Breathe Impacts Our Health: Improving Understanding of the Link between Air Pollution and Health", Environ. Sci. Technol., 50, 4895-4904, 2016.

Winterbourn, C. C.: Reconciling the chemistry and biology of reactive oxygen species, Nature Chem. Biol., 4, 278-286, 2008.

Zhao, H., Joseph, J., Zhang, H., Karoui, H., and Kalyanaraman, B.: Synthesis and biochemical applications of a solid cyclic nitrone spin trap: a relatively superior trap for detecting superoxide anions and glutathiyl radicals, Free Radical Biol. Med., 31, 599606, 2001.

Zhu, B. Z., Kalyanaraman, B., and Jiang, G. B.: Molecular mechanism for metal-independent production of hydroxyl radicals by 
hydrogen peroxide and halogenated quinones, P. Natl. Acad. Sci. USA, 104, 17575-17578, 2007a.

Zhu, B. Z., Zhao, H. T., Kalyanaraman, B., Liu, J., Shan, G. Q., $\mathrm{Du}$, Y. G., and Frei, B.: Mechanism of metal-independent decomposition of organic hydroperoxides and formation of alkoxyl radicals by halogenated quinones, P. Natl. Acad. Sci. USA, 104, 3698-3702, 2007b.

Zhu, B. Z., Shan, G. Q., Huang, C. H., Kalyanaraman, B., Mao, L., and Du, Y. G.: Metal-independent decomposition of hydroperoxides by halogenated quinones: detection and identification of a quinone ketoxy radical, P. Natl. Acad. Sci. USA, 106, 1146611471, 2009.
Ziemann, P. J. and Atkinson, R.: Kinetics, products, and mechanisms of secondary organic aerosol formation, Chem. Soc. Rev., 41, 6582-6605, 2012. 